\title{
Carter faces new dilemmas over non-proliferation
}

In the last of three articles about US attempts to regulate the social effects of science and technology, David Dickson describes the problems raised by President Carter's policy for controlling the spread of nuclear weapons

ONE of the main issues in the US presidential elections next year - just as it was when Jimmy Carter faced Gerald Ford three years ago - is likely to be whether the US should revise its attitude towards the relationship between the spread of nuclear energy and the proliferation of nuclear weapons.

Three years ago Carter gained considerable political capital from his firm stand against both the reprocessing of spent fuel and the development of fast breeder reactors, arguing that if not properly controlled, both could increase the risks of nuclear weapons proliferation - by encouraging production of weaponsusable plutonium. A week before the election he castigated President Ford's initiatives in the same direction as "too little and too late".

Now it is President Carter's own policies that are on trial. In particular attention has focussed on the results of the Nuclear NonProliferation Act (NNPA) passed overwhelmingly by Congress last year, and whether the strategy embodied in this act - attempting to control weapons proliferation through abrogation of commercial reprocessing and unilateral restrictions on uranium supply - remains the most appropriate direction to take.

Some argue that the apparent failure of the US to achieve a significant consensus in support of this strategy at the international level indicates inherent flaws. They point in particular to the provisional conclusions of the International Nuclear Fuel Cycle Evaluation (INFCE), set up at Carter's suggestion in 1977 and due to report formally next February, which are expected to give little support for the US strategy.

Others argue, conversely, that the administration has not been strict enough in applying its restrictions. "Many of us feel that there has been a great deal of backtracking by the administration, and that this seems to be accelerating rather than slowing down" said one Congressional aide last week, pointing for example to delays in implementing certain aspects of the act and the administration's apparent leniency in accepting conditions for the retransfer of spent nuclear fuels for reprocessing.

Three aspects of the proliferation issue are likely ot rekindle a public debate which has been relatively dormant since the signing of the NNPA last spring. The first is the failure of the US, despite cutting off economic and military aid, to dissuade Pakistan from what many believe to be its current attempts to develop nuclear weapons. "If Pakistan does explode a nuclear device, then it could have the same galvanising effect as Three Mile Island did," predicts one observer.

The second aspect is the growing economic crisis of the US nuclear power industry. At present the industry is still meeting past orders; but domestic orders have virtually dried up, and export orders may be the only way to keep the industry alive. But these are now seriously hampered by US non-proliferation policy.

The third factor affecting the debate will be the occurence of a number of international events focussing on the proliferation issue, including the domestic debate on a comprehensive test ban treaty (hopefully agreed in draft form by the US, USSR and UK in the near future), the review of the Non-Proliferation Treaty signed in 1970, and the outcome to the INFCE discussions.

\section{INFCE: technical or economic?}

Despite a relative lack of support for the thesis that the threat of proliferation requires of itself a reduced commitment to reprocessing and fast breeders (even though this may result de facto from technical and economic problems), US of ficials claim that the INFCE exercise has been a success in getting the link between plutonium production and the threat of proliferation firmly on the international agenda.

"INFCE has accomplished the largest part of what it was meant to do. As well as making a number of specific suggestions on way to go forward, it has been a process of international education, and despite difference between individual countries, there has been a considerable convergence over the past two years", says Dr Nye, one of the chief architects of the act and now Professor of Government at Harvard University.

However INFCE is unlikely to result in any major international shift towards the position so firmly enunciated by President Carter three years ago. (Indeed some suggest that the study may have been partly arranged to get the President off the hook). And despite the US administration's insistence that it was always intended as a technical exercise, and not a negotiating forum, scepticism of the US stance is based on the concern that technical exercises have been used as a front for political and economic interests.

Many European countries, for example, have accused the US of using its antireprocessing stand as a means of exploiting its market potential as a major supplier of enriched uranium, and of making up for its lack of progress in fast breeder design.

Political distrust also lies behind the rejection of US non-proliferation policies by Third World countries such as India and Pakistan. These countries see attempts by the US to prevent their access to nuclear technology, on any grounds, as an illegitimate infringement of sovreignty.

Domestically US politicians show little embarrassment for arguing that the US should use its position of nuclear hegemony to both articulate and justify its strategy on proliferation policy. "Unfortunately, certain countries have refused to see the wisdom of our position. If this situation persists, they may force the US to discontinue further nuclear collaboration," Representative Jonathan Bingham, one of the staunchest supporters of the NNPA, said recently.

At the same time, administration officials are increasingly concerned that the US position on non-proliferation strategy may be undermining the US's hegemony on nuclear issues in favour of various European countries - and that this could have wide economic and political implications.

Last week, for example, the Senate rejected a motion to discontinue research on the liquid metal fast breeder reactor at Clinch River in Tennesee (a long-time target of President Carter's). The main arguments for rejection were couched no so much in terms of its technical and economic appropriateness, severely questioned by the administration, but on the argument that the US is several years behind Europe in fast reactor design, and that this alone was sufficient reason for pressing ahead with the project.

Given the distrust that exists both in Europe and in the Third World over the political implications of the US nonproliferation strategy, one of the few statements that can be made with certainty is that international consensus is still a long way off - and that reaching such a consensus will be one of the major diplomatic tasks of the 1980s.

One major source of contention during the INFCE discussions, for example, has been on reaching agreement on the extent of global uranium supplies. Those opposed to the urgent need for reprocessing have argued, in support of their position, that global supplies are plentiful; those supporting both reprocessing and fast breeders support a much lower estimate, adding weight to their position.

The resulting assessment of supplies is likely to be an ambiguous compromise between these two positions, with a range of possible estimates. "The vocabulary may be largely technical, but the messages and stakes are highly political, and as such INFCE presents a fascinating case study in the interaction of science and politics," 


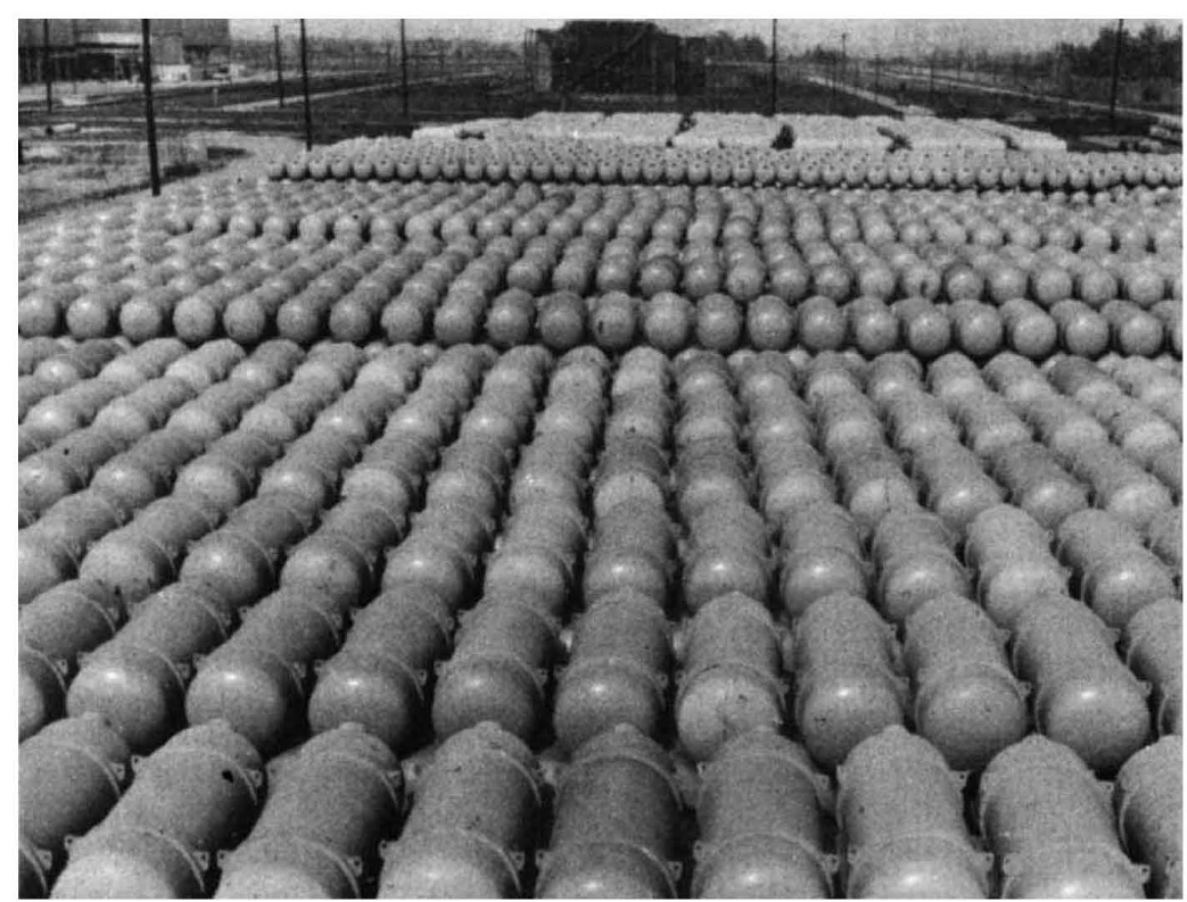

Canisters of uranium-238 stockpiled at Paducah, Kentucky - the 'spent fuel' that can be converted to plutonium in a fast breeder

commented Peter Clausen of the Department of Energy's Office of Energy Research in a recent issue of Arms Control Today.

Domestically, the provisions of the Nuclear Non-Proliferation Act have placed new demands on the agencies required to see that they are carried out in particular the Department of State, the Department of Energy, and the Nuclear Regulatory Commission.

The State Department, for example, has had to bear the brunt of external criticism of the administration's policies, particularly from countries with which it is actively seeking cooperation in other spheres; some critics claim that this has tempted the department to make compromises in carrying out its role - for example, in allowing reprocessing for the purposes of breeder research - that go considerably beyond Congress' original intentions.

The role of the Department of Energy, long an ally of the very industry which has been most affected by the NNPA, has also come under fire, critics claiming a conflict of interest between its functions of promoter and regulator of enriched uranium exports.

Finally several members of the Nuclear Regulatory Commission have expressed public disquiet about being asked to judge the adequacy of safeguards in countries which made requests for enriched uranium. This required the commission to play a direct foreign policy role for which it is ill-equipped.

"It is a major foreign policy action for an agency of the United States Government to go to a foreign country and say: we must inspect your facilities, we must inspect your system, before we will grant an export license. The NRC staff are not foreign policy experts," Commissioner John F Ahearne said in an address "Does the Emperor Have any Clothes?" given in New Orleans three weeks ago.

Government agencies, however, are not the only ones having difficulty with grappling with the issues thrown up by the debate proliferation. There are also deep differences in strategy among environmental groups concerned with the dangers of nuclear power in all its forms.

Some argue that the prime need is to define the technical parameters of the licensing process in a way that minimises the environmental impact of nuclear power. "We have tried to get political considerations out of export licensing," says Jacob Scherr of the Natural Resources Defense Council (NRDC), arguing against Commissioner Ahearne that it is possible to define criteria for the adequacy of safeguards that are "technical and objective".

Others, however, argue the case against nuclear technology on the more explicitly political grounds of opposition to the social and economic interests which it supports. "The NNPA is more a mechanism for sharing the nuclear market than an attempt to curtain nuclear weapons in the developing countries; certainly it is looked upon by these countries very cynically as a market control mechanism," says Bob Alvarez of the Environmental Policy Centre (EPC).

Such different perspectives can lead to a considerable divergence in policy. A particular case is over whether or not the US should fulfil its commitment to provide storage facilities for fuel which has been used on foreign reactors. Groups such as the NRDC argue with the administration that providing such storage, coupled with a guarantee of providing enriched uranium fuels, will take the pressure off the need for reprocessing facilities in foreign countries - and hence help reduce the chances of weapons proliferation.

In contrast, EPC and other nuclear groups argue that the US's provision of storage facilities would not only present a potential hazard to the US environment, but would also help encourage the spread of nuclear energy by getting other countries off the hook on the question of waste disposal. "Our philosophy is more concerned with restricting the spread of nuclear technology itself, rather than using a safeguard approach based on restricting the supply of nuclear materials,"' says Dr David Berrick of EPC.

Somewhat less predictably, the proliferation issue has also recently raised some difficult constitutional questions. These result from the recent publication of an article giving scientific and technical details of the construction of the hydrogen bomb, all claimed to be derived from public, non-classified information.

Finally there is the thorny question of how to deal with the Non-Proliferation Treaty when it comes up for review next year. At one level there is the question of the extent to which recent moves by the nuclear countries to restrict the export of "sensitive technologies"' contravene Title IV of the NPT, which promises "the fullest possible exchange of equipment, materials and scientific and technological information for the peaceful uses of nuclear energy."

Perhaps more fundamental is the fact that, as it currently stands, the treaty codifies an inherent inequality between weapons states and non-weapons states. This condition that may have appeared appropriate when the treaty was negotiated in the late 1960s; but it fits uneasily with the demands made for a new international economic order, implying a form of NorthSouth hegemony which many countries have demonstrated their unwillingness to accept by refusing to sign the treaty.

In the short-term, the Carter administration is now faced with the prospect of Pakistan exploding a nuclear device, and thus joining the "nuclear club" within the relatively near future. A state department study group was set up under the direction of $\mathrm{Mr}$ Smith late in August to discuss possible strategies by the US to prevent this, given that its current attempts to apply pressure through sanctions seem to have failed. And already some are suggesting that these sanctions should be stiffened.

In the long-run, there is the issue of whether a sufficient consensus - involving both developed and developing countries as partners in decision-making - can be forged to develop and apply an effective control regime; or whether increasing competition between both producers and consumers of nuclear power will be such as to limit the possibilities for multilateral action, shifting the focus back to bilateral actions. At this stage, nobody pretends to have all the answers. 